\title{
Biological Control Agents Against the Two-Spotted Spider Mite on Four Pepper Cultivars in Greenhouses
}

\author{
M. H.A. Mahgoub ${ }^{*}$; A. A. Abdallah ${ }^{* *}$ and E. M. A. El-Saiedy ${ }^{* * *}$ \\ ${ }^{*}$ Vegetable and Ornamental Acarology Dept., PPRI, Agric. Research Centre, Giza, Egypt (Dr.Mahagoub@yahoo.com) \\ ${ }^{* *}$ Agric. Zoology and Nematology Dept., Fac. of Agric., Al-Azhar Univ., Egypt \\ ${ }^{* * *}$ Plant Protection Dept., National Res. Centre, Dokii, Giza, Egypt
}

\begin{abstract}
The two predatory mites, Phytoseiulus persimilis Athias-Henriot and Neoseiulis californicus (McGregor) were used against the two-spotted spider mite, Tetranychus urticae Koch as well as the bio-pesticide product (Romachtin) on four pepper cultivars; two of which with red fruits ('Lorekii' and 'Depika') and the others with yellow fruits ('Llobii' and 'Cobly'). The two yellow cultivars (especially Llobii) were less susceptible to mite infestation than the two red cultivars. The used biological control agents reduced populations of all $T$. urticae stages on the aforementioned pepper cultivars. These reduction percentages revealed that, $N$. californicus gave the highest on the three pepper cultivars ('Lorekii', 'Depika' and 'Cobly'), while for the fourth cultivar, good results were obtained by both Romachtin or $P$. persimilis.
\end{abstract}

Key Words: Phytoseiid mites, Phytoseiulus persimilis, Neoseiulis californicus, Romachtin, Tetranychus urticae, Egypt.

\section{INTRODUCTION}

The pepper plant Capsicum annum $\mathrm{L}$. of the family: Solanaceae, has different cultivars planted in open fields and greenhouses in Egypt. Throughout the recent years, several cultivars of pepper plants with different coloured fruits started to appear in the local markets. The two-spotted spider mite, Tetranychus urticae Koch is one of the serious pests attacking glasshouse as well as field crops (Sabelis, 1981; Skirvin \& Williams, 1999; and Abdallah, 2002). Spider mites can colonize plants shortly after planting and damage usually occurs later during the growing season (Badii et al., 2004). Pesticides are the primary method for controlling this pest, but problems associated with developing resistance and residues on fruits appeared. Thus, integrated and biological pest management were proposed as alternative strategies. These new approaches in pest control, particularly use of natural compounds has recently received a considerable attention. The twospotted spider mite is commonly attacked by predators, of which phytoseiid mites have been used to suppress its population (Escudero and Ferragut, 2005). The most frequently used predatory mite is the specialist Phytoseiulus persimilis (McMurtry and Croft, 1997). It has been used as a bio-control agent in glasshouses since 1968 (Van Lenteren and Woets, 1988). There have been mass releases of $P$. persimilis by Oatman and McMurtry, 1966; Oatman et al., 1968; Simmonds, 1971 and Benuzzi \& Nicoli, 1991. Neoseiulus californicus seems also to be a promising candidate for combined release with $P$. persimilis. It has been used for biological control of spider mites in various field crops (McMurtry and Croft, 1997) and specific greenhouse crops (Calvitti \& Tsolakis, 1992 and Smith et al., 1993). It was released on greenhouse-grown vegetables for biological control of $T$. urticae (Castagnoli \& Falchini, 1993 and Pena \& Osborne, 1996).

The present work presents the use of two predatory mites, $P$. persimilis, $N$. californicus and the bio-pesticide product, Romachtin for the twospotted spider mite management on four pepper cultivars.

\section{MATERIALS AND METHODS}

Two different biological control agents ( $P$. persimilis and $N$. californicus) as predaceous mites and Romachtin as a bio-pesticide agent $(40 \mathrm{cc} / 100 \mathrm{~L}$. water) were practiced in a greenhouse at Qalubiea Governorate against $T$. urticae infesting four cultivars of pepper plants, of which two with yellow fruits ('Llobii' and 'Cobly') and other two with red fruits ('Lorekii' and 'Depika').

\section{Mass rearing of the phytoseiid mites:}

Both exotic predatory mite species, $P$. persimilis and $N$. californicus were obtained from cultures at Plant Protection Department, National Research Center, Giza, Egypt. Individuals of each predator species were mass-reared in the laboratory on freshly leaves of Ficus, Ficus discora L. arising on moisten cotton in aluminum trays $(30 \times 20 \times 7 \mathrm{~cm})$ provided with water. Tangle-foot (a mixture of Canada balsam and both castor and citronella oils) surrounding the edges of the tray was applied to prevent the mite from escaping. The trays were supplied with enough individuals of $T$. urticae different stages under room conditions. Water was added when needed maintaining suitable moisture. Groups from each predator species were transferred to potted bean plants, Phaseolus vulgaris L. infested with $T$. urticae as a prey then kept in muslin cages. 


\section{Releasing phytoseiid mites:}

When the density of T. urticae on pepper plants reached 10 individuals per leaf, the previous predators were released at the rate of 1 predator to 10 prey (Heikal and Fawzy, 2003). The total level of pest decrease was calculated using the formula reported by Çakmar, et al. (2005) as the following:

(T. urticae No./leaf) (leaf No./plant) (plants No./plot) The ratio of release

Predators release was taken place using leaves of beans harboring known numbers of predatory mites, put separately in polyethylene bags, tightly closed with rubber bands, then the bags were put in ice box at $8^{\circ} \mathrm{C}$ until reaching the pepper plants. The release was carried out $1-2 \mathrm{~h}$ before sunset. The leaves were hung between pepper leaves.

\section{Mites sampling:}

The population densities of T. urticae all stages and the cited predatory mites as well were recorded and monitored weekly for 28 weeks after bio-agents application. The randomized complete block design with ten replicates was used in each treatment. At each sampling date, 20 leaves were randomly selected from each treatment. Prey and predator counts were done using a stereomicroscope. Data obtained were analysized by ANOVA with the computer programme (SAS Institute, 1988) which runs under WIN to determine any significant difference between the means.

\section{RESULTS AND DISCUSSION}

Both predatory mites, $P$. persimilis and $N$. californicus as well as the bio-pesticide product, Romachtin succeeded at different degrees to control T. urticae infesting four cultivars of pepper plants [red fruits ('Lorekii' and 'Depika') and yellow fruits ('Cobly' and 'Llobii')]. Rasmy and El-Laithy (1988) released P. persimilis, Phytoseius finitimus Ribaga and Euseius scutalis (A. H.) to control T. urticae on greenhouse cucumber. Also in 2000, Walzer and Schausberger used $I$ '. persimilis and $N$. californicus to control T. urticae and T. cinnabarimus Bois. on cucumbers, while Çakmar et al. (2005) controlled the second pest in protected strawberries by the former predator in Turkey.

Table 1 indicated that the four pepper cultivars were infested with the two-spotted spider mite but the two cultivars of yellow fruits showed less infestation.

Average infestations, throughout the season were $22.23,17.06,6.62$ and 6.37 adult mites/leaf of Lorekii \& Depika (red fruits), and Cobly \& Llobii (yellow fruits), respectively.

Table 1 also documented that, the both predators, $P$. persimilis and $N$. californicus as well as the biopesticide; Romachtin reduced populations of T. urticae all stages on the four cultivars of pepper plants, versus it increased on the plants free of applications. Results also showed that the predatory mite, $N$. californicus gave the best results as decreasing average infestation through 28 weeks after application to 2.32, 2.23, 0.62 and 0.34 $T$. urticae adults/leaf of the aforementioned cultivars, respectively. Other mite stages followed similar trend. Here again, the reduction percentages as a result of releasing the two cited predators and Romachtin (Table 2) asserted that, $N$ californicus gave the highest reduction percentage of $\%$. wricate different stages on three pepper culuvars (Lorekii and 'Depika' as a red fruits and 'Cobly' as a yellow

Table (1): Average numbers of T. urticae different stages before and throughout 28 weeks aite: application with the two predatory mites, P. persimilis \& N. californicus and Romachtin on four pepper culitivars

\begin{tabular}{|c|c|c|c|c|c|c|c|c|c|}
\hline \multirow{4}{*}{$\begin{array}{l}\text { T. urticae } \\
\text { stages }\end{array}$} & \multirow{4}{*}{ Treatments } & \multicolumn{8}{|c|}{ Pepper cultivars } \\
\hline & & \multicolumn{4}{|c|}{ Red } & \multicolumn{4}{|c|}{ Yellow } \\
\hline & & \multicolumn{2}{|c|}{ Lorekii } & \multicolumn{2}{|c|}{ Depika } & \multicolumn{2}{|c|}{ Cobly } & \multicolumn{2}{|c|}{ bobi } \\
\hline & & Pre-count & Average & Pre-count & Average & Pre-count & Average & Pre-cul: & Awats \\
\hline \multirow{4}{*}{ Adults } & P. persinilis & 2.10 & 3.05 & 3.27 & 2.41 & 0.50 & 0.97 & 85 & 144 \\
\hline & N: californicus & 2.30 & 2.32 & 3.20 & 2.23 & 0.47 & 0.62 & $a 5$ & $\vdots \quad \cdots$ \\
\hline & Romachtin & 1.95 & 4.63 & 3.00 & 4.51 & $65 !$ & 157 & $\because 3$ & $\therefore$ \\
\hline & Control & 2.00 & 22.23 & 2.35 & 17.06 & 0.44 & 6.62 & 0.51 & $6 . \%$ \\
\hline \multirow{4}{*}{ Immatures } & P. persimilis & 4.60 & 18.37 & 5.83 & 15.04 & 0.64 & 1.46 & $02-4$ & 296 \\
\hline & N. californicus & 5.80 & 16.76 & 5.50 & 14.13 & 0.58 & 1.08 & 0.14 & 2.75 \\
\hline & Romachtin & 4.18 & 17.77 & 6.14 & 7.01 & 0.63 & 4.57 & $05:$ & 5.23 \\
\hline & Control & 4.50 & 82.91 & 5.00 & 79.20 & 0.56 & 17.19 & 0.50 & 18.76 \\
\hline \multirow{4}{*}{ Egges } & P. persimilis & 5.80 & 18.90 & 6.25 & 16.63 & 1.78 & 1.69 & 103 & 3.38 \\
\hline & N. califormicus & 7.50 & 1851 & 6.11 & 15.22 & 1.83 & 1.47 & 1.12 & 2.80 \\
\hline & Romachtin & 5.25 & $21.1 \%$ & 6.82 & 19.04 & 2.00 & 4.99 & 1.85 & 5.86 \\
\hline & Control & 5.50 & $79.5 \%$ & 6.45 & 76.59 & 1.18 & $18.2 !$ & 180 & 20.54 \\
\hline
\end{tabular}


Table (2): Reduction percentage of $T$. urticae different stages for 28 weeks after application with two predatory mites $P$. persimilis \& N. californicus and Romachtin on four cultivars of paper plants

\begin{tabular}{cccccc}
\hline \multirow{2}{*}{ Treatments } & T. urticae stages & \multicolumn{4}{c}{ Pepper cultivars } \\
\cline { 2 - 6 } & & \multicolumn{3}{c}{ Red } & \multicolumn{2}{c}{ Yellow } \\
\cline { 2 - 6 } P. persimilis & Adults & $81.32 \mathrm{ab}$ & $84.71^{\mathrm{a}}$ & $81.26^{\mathrm{ab}}$ & $78.61^{\mathrm{a}}$ \\
& Immatures & $76.81^{\mathrm{a}}$ & $88.03^{\mathrm{a}}$ & $91.35^{\mathrm{a}}$ & $72.43^{\mathrm{a}}$ \\
& Eggs & $75.12^{\mathrm{a}}$ & $81.55^{\mathrm{a}}$ & $92.42^{\mathrm{a}}$ & $74.51^{\mathrm{a}}$ \\
\hline \multirow{3}{*}{ N. californicus } & Adults & $86.85^{\mathrm{a}}$ & $83.88^{\mathrm{a}}$ & $89.02^{\mathrm{a}}$ & $72.68^{\mathrm{a}}$ \\
& Immatures & $83.72^{\mathrm{a}}$ & $88.06^{\mathrm{a}}$ & $95.12^{\mathrm{a}}$ & $54.20^{\mathrm{b}}$ \\
& Eggs & $82.06^{\mathrm{a}}$ & $82.38^{\mathrm{a}}$ & $95.38^{\mathrm{a}}$ & $75.32^{\mathrm{a}}$ \\
\hline \multirow{3}{*}{ Romachtin } & Adults & $70.60^{\mathrm{b}}$ & $61.67^{\mathrm{a}}$ & $74.64^{\mathrm{b}}$ & $67.60^{\mathrm{a}}$ \\
& Immatures & $75.94^{\mathrm{a}}$ & $81.40^{\mathrm{a}}$ & $73.13^{\mathrm{b}}$ & $78.08^{\mathrm{a}}$ \\
& Eggs & $70.33^{\mathrm{a}}$ & $71.90^{\mathrm{a}}$ & $79.86^{\mathrm{b}}$ & $76.95^{\mathrm{a}}$ \\
\hline
\end{tabular}

Means in the same row not followed by the same latter are significantly different, $\mathrm{p}<0.05$.

fruit), whereas the reduction percentage amounted $86.85,83.72 \& 82.06 \%$ of $T$. urticae adults, immatures and eggs on 'Lorekii' cultivar; 83.88, $88.06 \& 82.38 \%$ on 'Depika' cultivar and 89.02 , $95.12 \& 95.38 \%$ on 'Cobly' cultivar, respectively. This investigation is coincided with that reported by Hassan et al. (2007) who used the four predatory mites, $N$. californicus, $P$. macropilis (Banks), $N$. cucumeris (Oudemans) and $N$. zaheri (Yousef and El-Borolossy) for reducing populations of $T$. urticae and some other sucking insect pests on cucumber plants. However, for the fourth cultivar, 'Lliobii', good result was achieved by $P$. persimilis averaging $78.61,72.43$ and $74.51 \%$ for adult, immatures and, respectively. Results of Llobii may not be assured due to its low mite infestation.

Finally, it can be concluded that the predatory candidate, $N$. californicus gave the highest reduction percentage of all stages of $T$. urticae on only three cultivars of pepper plants ('Lorekii', 'Depika' and 'Cobly'), while gave moderate results on the fourth cultivar Llobii.

\section{REFERENCES}

Abdallah, A. A. 2002. Potential of predatory phytoseiid mites to control phytophagous mites. Ph.D. Thesis, Imperial College, London Univ., UK, $237 \mathrm{pp}$.

Badii, M. H.; Hernandez-Ortiz, E.; Flores, A. E. and Landeros, J. N. 2004. Prey stage preference and functional response of Euseius hibisci to Tetranychus urticae (Acari: Phytoseiidae, Tetranychidae). Exp. Appl. Acarol., 34: 263-273.

Benuzzi, M. and Nicoli, G. 1991. Phytoseiulus persimilis. Informatore Fitopatologico, 5: 41-46.

Çakmar, I.; Başpinar, H. and Madanlar, N. 2005. Control of the carmine spider mite, Tetranychus cinnabarinus Boisduval, by the predatory mite Phytoseiulus persimilis (Athias-Henriot), in protected strawberries in Aydm, Turkey. Turk. J. Agric. For., 29: 259-265.

Calvitti, M. and Tsolakis, H. 1992. Acari predatori fitseidi presenti su alcune colture erbacee nel lazio. Redia, 75 (2): 529-535.

Castagnoli, M. and Falchini, L. 1993. Suitability of Polyphagotarsonemus latus (Banks) (Acari: Tarsonemidae) as a prey for Amblyseius californicus (McGregor) (Acari Phytoseiidae). Redia, 75: 273-279.

Escudero, L. A. and Ferragut, F. 2005. Life-history of predatory mites Neoseiulus californicus and Phytoseiulus persimilis (Acari: Phytoseiidae) on four spider mite species as prey, with special reference to Tetranychus evansi (Acari: Tetranychidae). Biological Control, 32: 372-384

Hassan, M. F.; Ali, Fatma S.; Hussein, A. M. and Mahgoub, M. H. A. 2007. Control measurers of Tetranychus urticae Koch on two cucumber cultivars in plastic houses. Acarines: J. Egypt. Soc. Acarol., 1: 11-15.

Heikal, I. H. and Fawzy, M. M. 2003. A preliminary study of biological control of Tetranychus urticae Koch on cucumber (Acari: Tetanychidae). Egypt. J. Agric. Res., 81(1): 93-100.

McMurtry, J. A. and Croft, B. A. 1997. Life-styles of phytoseiid mites and their roles in biological control. Annu. Rev. Entomol., 42: 291-321.

Oatman, E. R. and McMurtry, J. A. 1966. Biological control of the two-spotted spider mite on strawberry in southern California. J. Econ. Entomol., 59: 433-439.

Oatman, E. R.; McMurtry, J. A. and Voth, V. 1968. Suppression of the two-spotted spider mite on strawberry with mass releases of Phytoseiulus persimilis. J. Econ. Entomol., 64: 1517-1521.

Pena, J. E. and Osborne, L. 1996. Biological control of Polyphagotarsonemus latus (Acarina: Tarsonemidae) in greenhouse and field trials using introductions of predacious mites (Acarina: 
Phytoseiidae). Entomophaga, 41: 279-285.

Rasmy, A. H. and El-Laithy, A. Y. M. 1988. Introduction of Phytoseiulus persimilis for twospotted spider mite control in greenhouses in Egypt (Acari: Phytoseiidae, Tetranychidae). Entomophaga, 33(4): 435-438.

Sabelis, M. W. 1981. Agricultural Research Report 910, Pudoc, Wageningen, The Netherlands.

SAS Institute. 1988. SAS/STAT User's Guide, Ver. 6.03. SAS Institute Inc., Cary, North Carolina, USA.

Simmonds, S. P. 1971. Observations on the possible control of Tetranychus urticae on strawberries by Phytoseiulus persimilis. Plant Pathoi., 20: 117-119.

Skirvin, D. J. and Williams, M. C. 1999. Differential effects of plant species on a mite pest (Tetranychus urticae) and its predator (Phytoseiulus persimilis): implications for biological control. Exp. Appl. Acarol., 23: 497512.

Smith, V. A.; Orr, D. B. and Hart, E. R. 1993. Economic analysis of two-spotted spider mite management on greenhouse-grown poplars. Tree Plant Notes. 44 (4): 154-156.

Van Lenteren, J. C. and Woets, J. 1988. Biological and integrated control in greenhouses. Annu. Rev. Entomol.. 33: 239-269.

Walzer, A. and Schausberger, P. 2000. Combined use of two predatory mite species for biological/integrated control of spider mites. Forderungsdienst, 48 (2): 50-51, 54-56. 